\title{
Reducing Nitrogen Loss in Subsurface Tile Drainage Water with Managed Drainage and Polymer-Coated Urea in a River Bottom Soil
}

\author{
Patrick R. Nash', Kelly A. Nelson², Peter P. Motavalli1 \\ ${ }^{1}$ Department of Soil, Environmental, and Atmospheric Sciences, University of Missouri, Columbia, USA \\ ${ }^{2}$ Division of Plant Sciences, University of Missouri, Columbia, USA \\ Email: nelsonke@missouri.edu
}

Received 23 June 2014; revised 21 July 2014; accepted 12 August 2014

Copyright (C) 2014 by authors and Scientific Research Publishing Inc.

This work is licensed under the Creative Commons Attribution International License (CC BY).

http://creativecommons.org/licenses/by/4.0/

(c) () Open Access

\section{Abstract}

Poorly-drained, river bottom soils can be high corn (Zea mays L.) yielding environments, but saturated soil conditions often reduce corn yields. Wabash soils located in river bottoms in Northeast Missouri have not been traditionally tile drained due to high clay content which requires narrow tile drain spacings. Increased land prices in the region have increased interest in tile draining poorly-drained bottom land soils to increase corn yields which could have a deleterious effect on water quality. The objectives of the three-year study were to determine whether use of managed subsurface drainage (MD) in combination with a controlled release $\mathrm{N}$ fertilizer could reduce the annual amount of $\mathrm{NO}_{3}^{-}-\mathrm{N}$ loss through tile drainage water compared to free subsurface drainage (FD) with a non-coated urea application. Annual $\mathrm{NO}_{3}^{-}-\mathrm{N}$ loss through tile drainage water with FD ranged from 28.3 to $90.1 \mathrm{~kg} \cdot \mathrm{N} \cdot \mathrm{ha}^{-1}$. Nitrogen fertilizer source did not affect $\mathrm{NO}_{3}^{-}-\mathrm{N}$ loss through tile drainage water, which was likely due to limited corn uptake over the three-year study due to adverse weather conditions. Averaged over three years, MD reduced tile water drained $52 \%$ and $\mathrm{NO}_{3}^{-}-\mathrm{N}$ loss $29 \%$ compared to FD. Reduction in $\mathrm{NO}_{3}^{-}-\mathrm{N}$ loss through tile drainage water with MD compared to FD was due to reduced tile flow during the non-cropping period. Annual flow-weighted mean concentration of $\mathrm{NO}_{3}^{-}-\mathrm{N}$ in the tile water was $5.8 \mathrm{mg} \cdot \mathrm{N} \cdot \mathrm{L}^{-1}$ with FD and $8.1 \mathrm{mg} \cdot \mathrm{N} \cdot \mathrm{L}^{-1}$ with $\mathrm{MD}$. Tile draining river bottom soils at this location for continuous corn production may not pose a health risk over the evaluated duration.

\section{Keywords}

Free Drainage, Managed Drainage, Nitrate, Nitrogen, Polymer-Coated Urea, Subsurface 


\section{Introduction}

Poorly-drained, silty clay soils in river bottoms located in Northeast Missouri and throughout the Midwestern U.S. often have high soil fertility [1] and can produce high corn yields. However, saturated soil conditions due to poor drainage, high seasonal water tables, and flooding due to the low landscape position often reduce corn yields. Soils of the Wabash soil series located in Northeast Missouri have a low overall soil hydraulic conductivity (Ksat $=0.01$ to $0.10 \mu \mathrm{m} \cdot \mathrm{sec}^{-1}$ ) due to high clay content throughout the soil profile, which requires narrow subsurface tile drain spacing. Therefore, poorly-drained Wabash soils have not traditionally been tile drained as the cost of installing subsurface tile drainage systems is relatively high. Increased land prices in the region [2] and relatively high grain prices may now make tile draining poorly-drained, river bottom soils that have not traditionally been drained an economically viable management option to reduce excessive soil moisture and increase corn yields.

The increased use of free subsurface drainage (FD) in agricultural fields has led to environmental concerns regarding $\mathrm{N}$ loading of surface waters [3]. An increased rate of water infiltration and transport out of soils with FD has increased N entering surface waters [4] [5]. Aquatic ecosystems can be sensitive to an anthropogenic addition of $\mathrm{N}$ as it is one of the most limiting nutrients in aquatic ecosystems. Nitrogen concentrations above natural levels in surface waters can result in hypoxia and eutrophication [3], which involves rapid algae growth and decomposition which in turn depletes oxygen levels below what is required for high forms of aquatic life [6]. Additionally, nitrate- $\mathrm{N}$ concentration above $10 \mathrm{mg} \cdot \mathrm{N} \cdot \mathrm{L}^{-1}$ in drinking water has been reported to cause health problems [7].

The potential for $\mathrm{NO}_{3}^{-}-\mathrm{N}$ entering surface waters as a result of agricultural fields with tile drainage is high due to $\mathrm{N}$ inputs and the high mobility of $\mathrm{NO}_{3}^{-}-\mathrm{N}$ in soil [6] [8]. Additionally, the recent shift toward continuous corn production could further increase $\mathrm{NO}_{3}^{-}-\mathrm{N}$ loss in tile drainage water as higher annual rates of $\mathrm{N}$ are required to obtain maximum yield compared to crop rotations with soybean, small grains, or forage grasses [9]. A three-year continuous corn study with $\mathrm{N}$ applied at $224 \mathrm{~kg} \cdot \mathrm{N} \cdot \mathrm{ha}{ }^{-1}$ annually, reported $\mathrm{NO}_{3}^{-}-\mathrm{N}$ loss through tile drainage water as high as $59 \mathrm{~kg} \cdot \mathrm{N} \cdot \mathrm{ha}^{-1}$ annually [10]. Annual flow-weighted mean concentration of $\mathrm{NO}_{3}^{-}-\mathrm{N}$ in tile water from fields in corn production can be greater than $10 \mathrm{mg} \cdot \mathrm{N} \cdot \mathrm{L}^{-1}$ [11] [12] and have been reported as high as $43 \mathrm{mg} \cdot \mathrm{N} \cdot \mathrm{L}^{-1}[10]$. However, drier conditions that reduce tile flow can result in higher flow-weighted mean concentrations of $\mathrm{NO}_{3}^{-}-\mathrm{N}$ in tile water compared to what would commonly be observed [13].

Research has shown up to $34 \%$ of the annual $\mathrm{NO}_{3}^{-}-\mathrm{N}$ loss through tile drainage water occurred during the non-cropping period [14]. A managed subsurface drainage system (MD) is similar to FD, except for the addition of a water level control structure, which allows for the control of tile drainage flow. Managed drainage has reduced annual water drained $30 \%$ to $50 \%$ compared to FD [14]-[16]. Annual reductions in $\mathrm{NO}_{3}^{-}-\mathrm{N}_{\text {loss }}$ in tile drainage water with MD compared to FD ranged from 32\% to 58\% [8] [10] [17]. The ability to reduce annual $\mathrm{NO}_{3}^{-}-\mathrm{N}$ loss through tile drainage water with MD compared to FD was derived from reducing the amount of water drained during the non-cropping period [4] [18].

Controlled-release, polymer-coated urea fertilizer (PCU) may further reduce $\mathrm{NO}_{3}^{-}-\mathrm{N}$ loss in tile drainage water flow. The rate of $\mathrm{N}$ release from PCU was a function of moisture and temperature [19]. In Missouri, PCU applied in April released less than 30\% urea-N into the soil by June when broadcast on the soil surface [20] and less than $40 \%$ when incorporated in the soil at a shallow depth $(2-5 \mathrm{~cm})$ [21]. The controlled-release of urea-N with this technology could reduce the availability of applied $\mathrm{N}$ until later in the growing season when soil conditions are less conducive to environmental $\mathrm{N}$ loss and when plant $\mathrm{N}$ uptake is greater. Noellsch et al. (2009) [22] reported that PCU increased corn $\mathrm{N}$ uptake $24 \%$ in a low-lying landscape position compared to non-coated urea (NCU). Nelson and Motavalli (2013) [23] reported PCU increased corn yield 7\% compared to NCU with FD.

Combining PCU with MD may greatly reduce early season $\mathrm{N}$ loss and increase corn uptake of applied $\mathrm{N}$ which could further reduce annual nitrate-N loss through tile drainage water. No research has evaluated the effect of PCU on $\mathrm{NO}_{3}^{-}-\mathrm{N}$ loss through tile drainage water flow. With a shift towards continuous corn production in the Midwestern U.S. and increasing environmental concern with water quality regarding $\mathrm{N}$ and subsurface tile drainage, research is needed to determine if combining PCU and MD management can reduce annual nitrate-N 
loss through tile drainage water. The objectives of the study were to 1) quantify the average concentration and annual loss of $\mathrm{NO}_{3}^{-}-\mathrm{N}$ in tile drain water from a poorly-drained river bottom soil, and 2) determine whether MD with PCU could reduce $\mathrm{NO}_{3}^{-}-\mathrm{N}$ loss in tile water compared to FD with NCU.

\section{Materials and Methods}

\subsection{Site Description and Experimental Design}

This three-year study (June, 2010 to June 2013) was conducted on a private farm production field in a river bottom soil located in Northeast Missouri $\left(40^{\circ} 3^{\prime} 11.5^{\prime \prime} \mathrm{N}, 92^{\circ} 4^{\prime} 21.2^{\prime \prime} \mathrm{W}\right)$. The investigation was part of a larger project evaluating the effects of subsurface tile drainage and $\mathrm{N}$ fertilizer source on continuous corn production [24]. Subsurface tile drains (10.2 cm diameter, perforated plastic tubing) and water level control structures (AgriDrain Corporation, Adair, IA) were installed in the summer prior to the initiation of the study in April 2010. Tile drains were installed at a depth of $0.9 \mathrm{~m}$ with $6.1 \mathrm{~m}$ spacings. An additional $6.1 \mathrm{~m}$ separated each plot in order to limit movement of water and $\mathrm{N}$ into adjacent plots (Figure 1). Plots were 18 by $366 \mathrm{~m}$ long. Study years represented the period of time from application of $\mathrm{N}$ in the spring until the application of $\mathrm{N}$ the following season (Table 1).

The study was arranged as a two-way factorial, two-replication, randomized complete-block design. Treatments included drainage (FD and MD) in combination with $\mathrm{N}$ fertilizer sources [NCU and PCU (ESN, Agrium Advanced Technology, Denver, CO)]. Nitrogen fertilizer was broadcast applied at $202 \mathrm{~kg} \cdot \mathrm{N} \cdot \mathrm{ha}^{-1}$ and incorporated into the soil $(5-10 \mathrm{~cm})$ directly after application and prior to planting (Sunflower disk harrow, Beloit, KS). Deep tillage (Blu-Jet, SubTiller 4, Thurston Manufacturing Company, Thurston, NE) was used after harvest as a form of residue management. Harvest did not occur in 2010 as a flood in June 2010 resulted in a total crop failure. Field site management including $\mathrm{N}$ application rates and dates, plant dates, harvest dates, and water level control with MD can be found in Table 1.

The soil type was a Wabash silty clay (fine, smectitic, mesic Cumulic Vertic Endoaquolls) located in a river bottom. Soil samples (composites of three subsamples) were collected from each plot to a depth of 0.0 to $0.3 \mathrm{~m}$, 0.3 to $0.6 \mathrm{~m}$, and 0.6 to $0.9 \mathrm{~m}$ in the fall after harvest each year using a Giddings hydraulic probe (Giddings Machine Company, Windsor, CO) fitted with a $4.5 \mathrm{~cm}$ diameter steel probe. Soil properties combined over plots are presented by depth over years in Table 2 were analyzed using standard soil testing analytical procedures for Missouri [25]. Soil $\mathrm{NH}_{4}^{+}-\mathrm{N}$ and $\mathrm{NO}_{3}^{-}-\mathrm{N}$ concentrations were converted from mg. $\mathrm{kg}^{-1}$ to $\mathrm{kg} \cdot \mathrm{ha}^{-1}$ based on soil bulk density measurements taken at the depths of $0-0.3,0.3-0.6$, and $0.6-0.9 \mathrm{~m}$ at the field site in 2013. Daily rainfall was measured on-site using a rain gauge and datalogger (Automata, Nevada City, CA).

\subsection{Water Sample Collection, Flow, and Nitrate Loss Measurements}

Pressure transducers (American Sensor Technologies, Mount Olive, NJ) measured water height year-round in each plot's water-level control structure. Water height was measured every five minutes, and dataloggers stored the data (Automata, Nevada City, CA). During periods of flow in 2012 and 2013, daily water height readings were recorded manually in the water-level control structures using a Little Dipper field instrument (Heron Instruments, Dundas, Ontario), as a means of data quality assurance. Flow rates were obtained by subtracting the height of the slides from the water height readings in the control structures and then using the equation:

$$
\text { Flow rate }\left(\mathrm{L} \cdot \mathrm{m}^{-1}\right)=1.4533 * \text { Flow depth }(\mathrm{cm})^{2}
$$

The equation, obtained through laboratory testing [26], was specific to the dimensions of the water-level control structures and angle of the top weir slides used in the study. Flow rates were divided by the area drained $(12.2 \times 366 \mathrm{~m})$ to obtain measurements of flow over time and area, which estimated total daily flow from each plot.

Portable automated water samplers (Teledyne ISCO, Lincoln, NE) were used in conjunction with liquid level actuators (Teledyne ISCO, Lincoln, NE) to collect water samples every six hours when flow was present. Water samples were combined into daily composite samples. During winter, water samples were manually collected approximately every other day when flow was present. Tile drainage water samples were stored in a refrigerator $\left(5^{\circ} \mathrm{C}\right)$ and filtered $(1.5 \mu \mathrm{m}, 934-\mathrm{AH}$, Whatman Glass Microfiber, General ElectricBio-Sciences, Pittsburgh, PA) prior to being analyzed for $\mathrm{NO}_{3}^{-}-\mathrm{N}$ concentration (10-107-04-1-F Quick Chem) using an automated ion analyzer (Lachat Quik Chem 8000, Loveland, CO). 


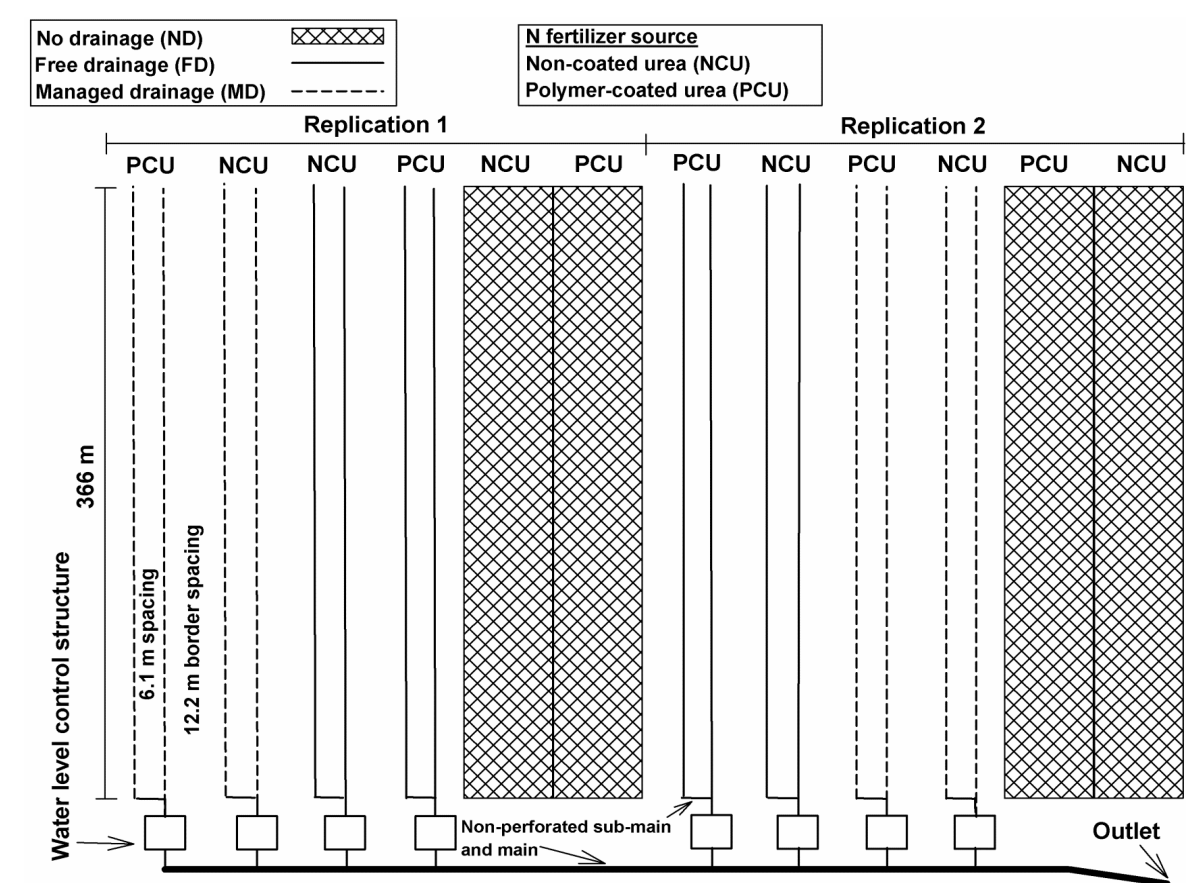

Figure 1. Field layout and plot treatments, including the subsurface tile drainage design.

Table 1. Field site management including fertilizer applications, plant and harvest dates, and water level control management with managed drainage during the study.

\begin{tabular}{|c|c|c|c|}
\hline Field site management & 2010 & 2011 & 2012 \\
\hline $\mathrm{N}$ fertilizer application & 28 June 2010 & 8 May 2011 & 14 May 2012 \\
\hline Rate $\left(\mathrm{kg} \cdot \mathrm{N} \cdot \mathrm{ha}^{-1}\right)$ & 202 & 202 & 202 \\
\hline Planting date & 29 June 2010 & 9 May 2011 & 15 May 2012 \\
\hline Rate (seeds $\cdot$ ha $^{-1}$ ) & 79,000 & 79,000 & 79,000 \\
\hline Harvest date $\mathrm{e}^{\dagger}$ & - & 7 Nov. 2012 & 9 Nov. 2012 \\
\hline Water level control—Free drainage mode & 28 Jun. 2010 & 25 Mar. 2011 & 23 Mar. 2012 \\
\hline Water level control—Managed drainage mode & 6 Aug. 2010 & 13 July 2011 & 25 May 2012 \\
\hline Water level control—Free drainage mode & $-^{\ddagger}$ & 8 Oct. 2011 & - \\
\hline Water level control—Managed drainage mode & - & 13 Dec. 2011 & - \\
\hline
\end{tabular}

${ }^{\dagger}$ Corn crop was lost in 2010 due to a flood. ${ }^{\ddagger}$ Not applicable.

Table 2. Selected soil chemical properties from fall soil analysis at depths of 0 to $0.3,0.3$ to 0.6 , and 0.6 to $0.9 \mathrm{~m}$ in 2010 , 2011, and 2012. Data were averaged over tile drainage systems and N fertilized sources.

\begin{tabular}{|c|c|c|c|c|c|c|c|c|c|c|c|}
\hline \multirow[b]{2}{*}{ Year } & \multirow[b]{2}{*}{ Depth } & \multirow[b]{2}{*}{$\mathrm{pH}$} & \multirow[b]{2}{*}{ Organic matter } & \multicolumn{8}{|c|}{ Exchangeable (1 $\left.\mathrm{M} \mathrm{NH}_{4} \mathrm{AOc}\right)$} \\
\hline & & & & Neut. acidity & $\mathrm{CEC}^{\dagger}$ & Bray I P & $\mathrm{Ca}$ & $\mathrm{K}$ & $\mathrm{Mg}$ & $\mathrm{NH}_{4}^{+}-\mathrm{N}$ & $\mathrm{NO}_{3}^{-}-\mathrm{N}$ \\
\hline & $\mathrm{m}$ & $0.01 \mathrm{M} \mathrm{CaCl}_{2}$ & $\mathrm{~g} \cdot \mathrm{kg}^{-1}$ & $\mathrm{cmol}_{\mathrm{c}} \cdot \mathrm{kg}$ & & $\mathrm{mg} \cdot \mathrm{kg}^{-1}$ & & & $\mathrm{~kg} \cdot \mathrm{ha}^{-}$ & & \\
\hline \multirow[t]{3}{*}{2010} & $0-0.3$ & 5.2 & 26.0 & 5.1 & 27.7 & 46.5 & 8368 & 242 & 992 & 18.3 & 24.8 \\
\hline & $0.3-0.6$ & 5.3 & 18.9 & 4.3 & 26.4 & 13.3 & 8026 & 191 & 1071 & 14.3 & 11.5 \\
\hline & $0.6-0.9$ & 5.6 & 14.3 & 2.7 & 26.1 & 12.6 & 8321 & 208 & 1243 & 13.2 & 9.7 \\
\hline \multirow[t]{3}{*}{2011} & $0-0.3$ & 5.4 & 31.4 & 4.2 & 25.5 & 44.2 & 7671 & 395 & 1003 & 32.9 & 14.1 \\
\hline & $0.3-0.6$ & 5.9 & 24.6 & 2.4 & 26.3 & 11.6 & 8422 & 371 & 1252 & 18.2 & 11.5 \\
\hline & $0.6-0.9$ & 6.3 & 18.5 & 0.9 & 24.2 & 6.3 & 8117 & 387 & 1284 & 15.6 & 8.8 \\
\hline \multirow[t]{3}{*}{2012} & $0-0.3$ & 5.1 & 26.8 & 5.8 & 25.8 & 58.4 & 7255 & 256 & 928 & 16.1 & 47.7 \\
\hline & $0.3-0.6$ & 5.5 & 20.3 & 3.7 & 25.5 & 9.5 & 7745 & 220 & 1155 & 5.5 & 14.1 \\
\hline & $0.6-0.9$ & 5.9 & 14.9 & 2.0 & 23.7 & 4.2 & 7575 & 219 & 1208 & 5.3 & 6.7 \\
\hline
\end{tabular}

${ }^{\dagger}$ Abbreviations: CEC = cation exchange capacity; Neut. = neutralizable. 


\subsection{Statistical Analysis}

Soil $\mathrm{N}$ concentration, water drained, $\mathrm{NO}_{3}^{-} \mathrm{N}$ loss, and flow-weighted mean concentration of $\mathrm{NO}_{3}^{-}-\mathrm{N}$ in the tile drainage water by drainage period (FD period, MD period, and cumulative) and study year were statistically analyzed for treatment effects using ANOVA and PROC GLM with SAS v9.3 [27]. Soil $\mathrm{NH}_{4}^{+}-\mathrm{N}$ and $\mathrm{NO}_{3}^{-}-\mathrm{N}$ concentration after harvest was only affected by depth and year. Water drained, $\mathrm{NO}_{3}^{-}-\mathrm{N}$ loss, and flowweighted mean concentration of $\mathrm{NO}_{3}^{-}-\mathrm{N}$ in the tile drainage water were not affected by $\mathrm{N}$ fertilizer source or year, but were affected by subsurface drainage system. Significant differences in treatment means were determined using Fisher's Protected LSD at $\mathrm{P}=0.05$ or 0.10 .

\section{Results and Discussion}

\subsection{Precipitation}

The intensity and distribution of precipitation varied over the three year study (July, 2010 through May, 2013) (Figure 2). High precipitation throughout the 2010 growing season resulted in two flood events (June and September), which resulted in a complete crop failure. Precipitation over the period of July through September, 2010 was 532 mm, which was 280 and 349\% greater than in 2012 and 2011, respectively. From October 2010 through March 2011, precipitation totaled $147 \mathrm{~mm}$. Similar to 2010, high intensity precipitation during the spring resulted in a flood event in June; however, crop failure did not occur in 2011. Precipitation over the period of April through June, 2011 was 402 mm, which was 51\% greater than in 2012. From July through October 2011, precipitation was low $(168 \mathrm{~mm})$ which resulted in drought conditions. Precipitation in November 2011 was high (226 mm), while precipitation from December 2011 through February 2012 was $184 \mathrm{~mm}$ which was common for the region and similar to 2010-2011 and 2012-2013. Drought conditions occurred through the spring, summer, and fall in 2012. High intensity precipitation events during the non-cropping period in April and June of 2013 (454 mm) resulted in multiple flooding events.

\subsection{Soil Nitrogen Concentration}

Excessive or lack of precipitation significantly $(\mathrm{P} \leq 0.05)$ affected soil $\mathrm{NH}_{4}^{+}-\mathrm{N}$ and $\mathrm{NO}_{3}^{-}-\mathrm{N}$ after harvest at the depths of 0 - 0.3, 0.3 - 0.6 and 0.6 - 0.9 m over the three-year study (Table 3). From 2010 to 2011, soil $\mathrm{NH}_{4}^{+}-\mathrm{N}$ concentration increased from 16.3 to $33.6 \mathrm{~kg} \cdot \mathrm{N} \cdot \mathrm{ha}^{-1}$ at 0 to $0.3 \mathrm{~m}$ depth, 14.6 to $18.4 \mathrm{~kg} \cdot \mathrm{N} \cdot \mathrm{ha}^{-1}$ at 0.3 to $0.6 \mathrm{~m}$ depth, and 12.8 to $16.2 \mathrm{~kg} \cdot \mathrm{N} \cdot \mathrm{ha}^{-1}$ at 0.6 to $0.9 \mathrm{~m}$ depth. Soil $\mathrm{NH}_{4}^{+}-\mathrm{N}$ concentration in 2012 compared to 2010 was similar at the 0 to $0.3 \mathrm{~m}$ depth, and less at the 0.3 to $0.9 \mathrm{~m}$ depth. High soil $\mathrm{NH}_{4}^{+}-\mathrm{N}$ concentration in 2011 was presumably due to low precipitation throughout the summer and fall that limited the conversion of $\mathrm{NH}_{4}^{+}-\mathrm{N}$ to $\mathrm{NO}_{3}^{-}-\mathrm{N}$. Soil $\mathrm{NO}_{3}^{-}-\mathrm{N}$ concentration at a 0.3 to $0.9 \mathrm{~m}$ depth was similar from 2010 to 2012. However, the soil $\mathrm{NO}_{3}^{-}-\mathrm{N}$ at 0 to $0.3 \mathrm{~m}$ depth was $14.8 \mathrm{~kg} \cdot \mathrm{N} \cdot \mathrm{ha}^{-1}$ in 2011 which was lower than $2010\left(26.4 \mathrm{~kg} \cdot \mathrm{N} \cdot \mathrm{ha}^{-1}\right)$ and $2012\left(46.5 \mathrm{~kg} \cdot \mathrm{N} \cdot \mathrm{ha}^{-1}\right)$. The relatively high soil $\mathrm{NO}_{3}^{-}-\mathrm{N}$ concentration in 2010 was presumably due to high precipitation and limited corn $\mathrm{N}$ uptake due to complete crop failure. In 2012, soil $\mathrm{NO}_{3}^{-}-\mathrm{N}$ concentration was greater than in 2010 and 2011, which was likely due to drought conditions throughout the spring and summer that limited environmental $\mathrm{N}$ loss and corn $\mathrm{N}$ uptake which was followed by high precipitation in the fall prior to harvest and soil sampling. Therefore, dry early growing season conditions in combination with wet fall conditions probably increased the potential for $\mathrm{NO}_{3}^{-}-\mathrm{N}$ loss during the non-cropping period, and subsequently increased the potential for reducing annual $\mathrm{NO}_{3}^{-}-\mathrm{N}$ with MD compared to FD.

\subsection{Tile Water Drained}

Cumulative water drained over each study year ranged from 800 to $1150 \mathrm{~mm}$ with FD and 201 to $691 \mathrm{~mm}$ with MD (Figure 2). Throughout the three-year study, tile flow was constant with FD and with MD when in FD mode, except for drought periods that began in July and extended into the fall. Persistent tile flow was likely a result of a high water table due to the low landscape position and resulted in high amounts of water drained in relation to the amount of precipitation received. Averaged over the three-year study, MD drained $487 \mathrm{~mm}$ which was 52\% lower than the $1020 \mathrm{~mm}$ drained with FD (Table 4). This was similar to greater than the $30 \%$ to $50 \%$ reductions in annual water flow with MD compared to FD reported in upland soils [14]-[16]. In two of the three years, tile flow with MD was generally limited to April through June due to mild and extreme drought conditions 


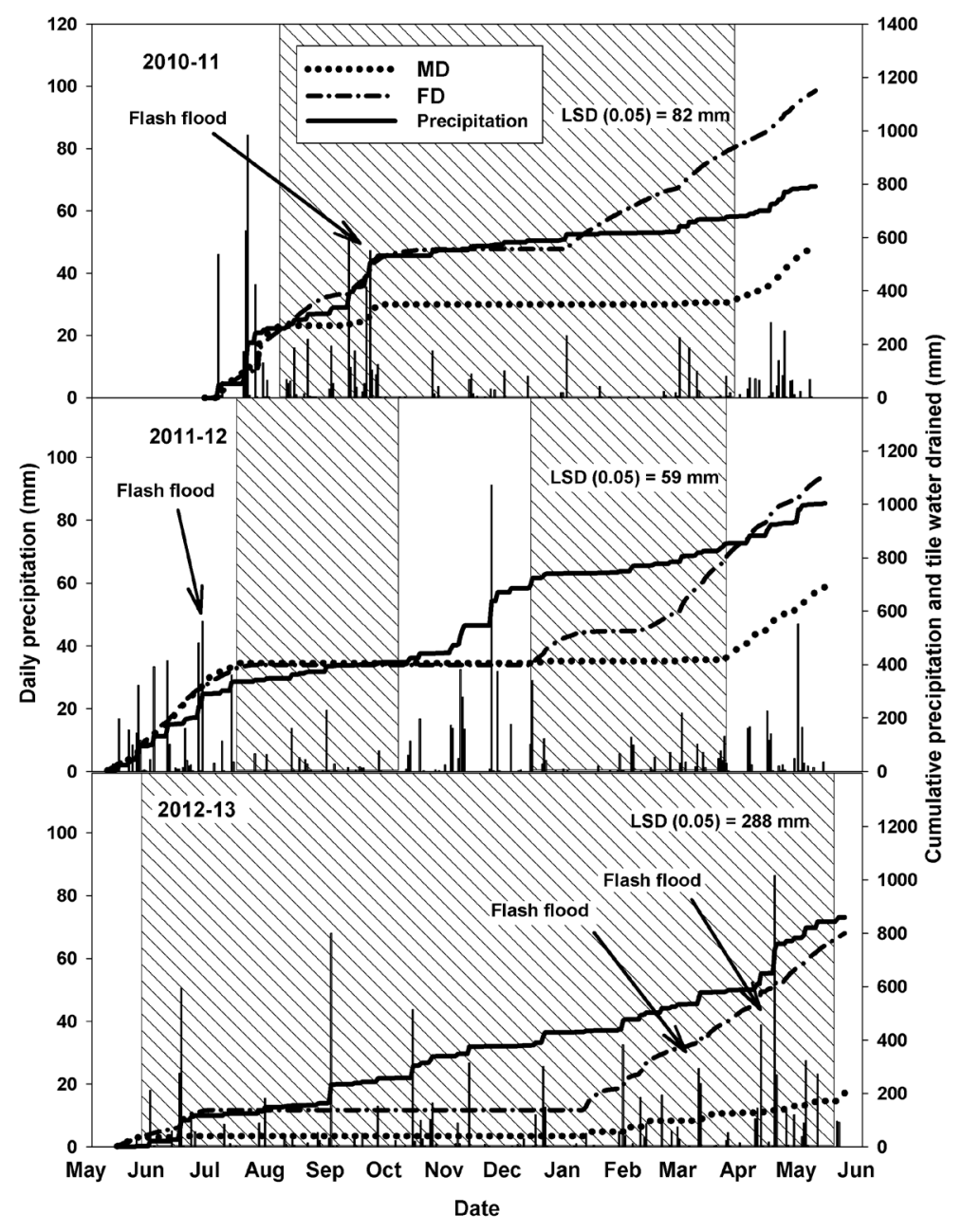

Figure 2. Daily precipitation (bars), cumulative precipitation (solid lines), and tile water drained (dashed/dotted lines) by tile drainage system (FD = free drainage system and MD = managed drainage system) and years. The start of each study year corresponds to the spring $\mathrm{N}$ application. Shaded areas represent the period of time that MD treatments were in managed drainage mode.

Table 3. Effect of year and depth on soil $\mathrm{NH}_{4}^{+}-\mathrm{N}$ and $\mathrm{NO}_{3}^{-}-\mathrm{N}$ concentrations after harvest. Data were averaged over $\mathrm{N}$ fertilizer source and drainage treatments.

\begin{tabular}{|c|c|c|c|c|c|c|}
\hline \multirow[b]{2}{*}{ Depth (m) } & \multicolumn{3}{|c|}{ Soil $\mathrm{NH}_{4}^{+}-\mathrm{N}$} & \multicolumn{3}{|c|}{ Soil $\mathrm{NO}_{3}^{-}-\mathrm{N}$} \\
\hline & 2010 & 2011 & 2012 & 2010 & 2011 & 2012 \\
\hline & \multicolumn{3}{|c|}{$\mathrm{kg} \cdot \mathrm{N} \cdot \mathrm{ha}^{-1}$} & \multicolumn{3}{|c|}{$\mathrm{kg} \cdot \mathrm{N} \cdot \mathrm{ha}^{-1}$} \\
\hline $0-0.3$ & 16.3 & 33.6 & 16.4 & 26.4 & 14.8 & 46.5 \\
\hline $0.3-0.6$ & 14.6 & 18.4 & 5.6 & 11.2 & 11.3 & 13.2 \\
\hline $0.6-0.9$ & 12.8 & 16.2 & 5.1 & 9.8 & 8.5 & 6.1 \\
\hline $\operatorname{LSD}(\mathrm{P}=0.05)$ & \multicolumn{3}{|c|}{3.7} & \multicolumn{3}{|c|}{9.1} \\
\hline
\end{tabular}

during the summer and fall. The average reduction in water drained over a study year was due primarily to restricted tile water flow with MD during the summer and non-cropping period. Managed drainage reduced tile flow $86 \%(84 \mathrm{~mm})$ compared to FD $(612 \mathrm{~mm})$ during the summer and non-cropping period. Drury et al. (2009) [14] reported a $44 \%$ reduction in water drained with MD compared to FD over the non-cropping period. A greater reduction in water drained over the non-cropping period in this study may be due to greater tile flow over 
Table 4. Effect of drainage water management system on tile water drained, $\mathrm{NO}_{3}^{-}-\mathrm{N}$ loss through tile water flow, and flow-weighted mean concentration of $\mathrm{NO}_{3}^{-}-\mathrm{N}$ averaged over three years.

\begin{tabular}{|c|c|c|c|c|c|c|c|c|c|}
\hline \multirow[b]{2}{*}{ Drainage } & \multicolumn{3}{|c|}{ Tile water drained $^{\dagger}$} & \multicolumn{3}{|c|}{$\mathrm{NO}_{3}^{-}-\mathrm{N}$ loss through tile water } & \multicolumn{3}{|c|}{ Flow-weighted mean } \\
\hline & FD period ${ }^{\ddagger}$ & MD period & Cumulative $^{\S}$ & FD period & MD period & Cumulative & FD period & MD period & Annual \\
\hline & \multicolumn{3}{|c|}{$\mathrm{mm}$} & \multicolumn{3}{|c|}{$\mathrm{kg} \mathrm{NO}_{3}^{-}-\mathrm{Nha}^{-1}$} & \multicolumn{3}{|c|}{$\mathrm{mg} \mathrm{NO}_{3}^{-}-\mathrm{N} \mathrm{L}^{-1}$} \\
\hline FD & 407 & 612 & 1020 & 25.7 & 25.4 & 51.1 & 5.9 & 4.7 & 5.8 \\
\hline MD & 404 & 84 & 487 & 28.7 & 7.8 & 36.5 & 6.1 & 10.6 & 8.1 \\
\hline $\mathrm{LSD}^{\pi}$ & NS & $112^{*}$ & $85^{*}$ & NS & $8.6^{*}$ & 12.2 & NS & $3.0^{*}$ & $1.8^{*}$ \\
\hline
\end{tabular}

${ }^{\dagger}$ Abbreviations: $\mathrm{FD}=$ free drainage; $\mathrm{LSD}=$ least significant difference; $\mathrm{MD}=$ managed drainage; $\mathrm{NS}=$ not significant. ${ }^{\ddagger} \mathrm{FD}$ period represents the period of time that tile flow was not restricted with MD, while MD period represents the period of time when tile flow was restricted with MD. ${ }^{\S}$ Cumulative or annual represents the period of time from application of $\mathrm{N}$ at planting until the application of $\mathrm{N}$ in the following year. "A single asterisk following an LSD value represents a P-level of 0.05 and no asterisk represents a P-level of 0.10 .

the winter period due to limited freezing of the soil compared to soils in Ontario, Canada.

\subsection{Nitrate-N Concentration and Loss in Tile Drainage Water}

Cumulative $\mathrm{NO}_{3}^{-}-\mathrm{N}$ loss averaged over the three study years ranged from $28.3(2010-2011)$ to $90.1 \mathrm{~kg} \cdot \mathrm{N} \cdot \mathrm{ha}{ }^{-1}$ (2011-2012) with FD (Figure 3), which was likely due to differences in tile flow, soil N concentration, and plant uptake. Previous research studies on continuous corn with FD have reported that annual $\mathrm{NO}_{3}^{-}-\mathrm{N}$ loss through tile drainage water increased from 4 to $59 \mathrm{~kg} \cdot \mathrm{N} \cdot \mathrm{ha}^{-1}$ due to carry-over $\mathrm{N}[10]$ and 16.5 to $47.8 \mathrm{~kg} \cdot \mathrm{N} \cdot \mathrm{ha}^{-1}$ due to the application of $\mathrm{N}$ in the fall compared to spring [28]. Average $\mathrm{NO}_{3}^{-}-\mathrm{N}$ loss through tile drainage water over a study year ranged 12.8 (2012-2013) to $70.2 \mathrm{~kg} \cdot \mathrm{N} \cdot \mathrm{ha}^{-1}$ (2011-2012) with MD. Similar to Gast et al. (1978) [10], high $\mathrm{NO}_{3}^{-}$-N loss in the tile drainage water over the 2011-2012 study year was likely due to wet spring conditions and carry-over $\mathrm{N}$, which resulted in approximately $60 \mathrm{~kg} \mathrm{NO}-\mathrm{NO}_{3}^{-}-\mathrm{N} \mathrm{ha}^{-1}$ of loss for both $\mathrm{FD}$ and MD during the FD period from 9 May through 12 July, 2011. Additionally, a presumably high water table due to the low landscape position of the river bottom soil likely contributed to tile flow and the high annual $\mathrm{NO}_{3}^{-}-\mathrm{N}$ loss through the tile drainage water, as compared to the annual 6 to $66 \mathrm{~kg} \mathrm{NO}_{3}^{-}-\mathrm{N} \mathrm{ha}^{-1}$ loss reported in previous research with FD on upland soils in corn production [12] [28]-[30].

Nitrogen fertilizer source did not affect cumulative $\mathrm{NO}_{3}^{-}-\mathrm{N}$ loss over the three-year study. Nitrogen presumably was not a limiting factor over the experiment due to dry summer and fall conditions that limited gaseous $\mathrm{N}$ loss and corn $\mathrm{N}$ uptake in combination with annual applications of $202 \mathrm{~kg} \cdot \mathrm{N} \cdot \mathrm{ha}^{-1}$. Averaged over three-years, cumulative $\mathrm{NO}_{3}^{-}-\mathrm{N}$ loss though tile drainage water with $\mathrm{MD}\left(36.5 \mathrm{~kg} \cdot \mathrm{N} \cdot \mathrm{ha}^{-1}\right)$ was significantly $(\mathrm{P} \leq 0.10)$ reduced $29 \%$ compared to FD (51.1 kg. $\mathrm{N} \cdot \mathrm{ha}^{-1}$ ) (Table 4). Previous research studies on upland soils have reported $32 \%$ to $58 \%$ reduction in annual $\mathrm{NO}_{3}^{-}-\mathrm{N}$ loss through tile drainage water with MD compared to FD, which was attributed to reductions in the annual water drained with MD [14] [17] [18]. Although water drained over a study year was reduced $52 \%$ on average with $\mathrm{MD}$ compared to $\mathrm{FD}, \mathrm{NO}_{3}^{-}-\mathrm{N}$ loss was only reduced by $29 \%$. Higher $\mathrm{NO}_{3}^{-}-\mathrm{N}$ concentration in the tile water observed at times with MD compared to FD over the three-year study partially offset the reduction in water drained and subsequent $\mathrm{NO}_{3}^{-}-\mathrm{N}$ loss through tile drainage water with $\mathrm{MD}$ (Figure 3). Increased $\mathrm{NO}_{3}^{-}-\mathrm{N}$ concentration in the tile drainage water with MD compared to FD was likely due the annual reduction in tile flow and limited corn uptake of applied $\mathrm{N}$ which may have increase soil $\mathrm{N}$ concentration.

Over the FD period, $\mathrm{NO}_{3}^{-}-\mathrm{N}$ loss was similar between FD $\left(25.7 \mathrm{~kg} \cdot \mathrm{N} \cdot \mathrm{ha}^{-1}\right)$ and $\mathrm{MD}\left(28.7 \mathrm{~kg} \cdot \mathrm{N} \cdot \mathrm{ha}^{-1}\right)$ on average (Table 4). While over the MD period, $\mathrm{MD}$ significantly $(\mathrm{P} \leq 0.05)$ reduced $\mathrm{NO}_{3}^{-}-\mathrm{N}$ loss $69 \%$ compared to FD due to an $86 \%$ reduction in water drained over that period. In Ontario, Drury et al. (2009) [14] reported a $38 \%$ reduction in $\mathrm{NO}_{3}^{-}-\mathrm{N}$ loss over the non-cropping period with MD compared to $\mathrm{FD}$, which was due to a $34 \%$ reduction in water drained over non-cropping period. Greater reduction in water drained and subsequent $\mathrm{NO}_{3}^{-}-\mathrm{N}$ loss over the non-cropping period in this study may have been due to reduced freezing of the soil in Missouri as compared to in Ontario, Canada. These results indicate the potential to reduce the annual $\mathrm{NO}_{3}^{-}-\mathrm{N}$ loss from tile drainage with MD may be greater in warmer climates with less potential for freezing of soil during the noncropping period.

\subsection{Flow-Weighted Mean Concentration of Nitrate- $\mathrm{N}$ in Tile Drainage Water}

Similar to water drained and $\mathrm{NO}_{3}^{-}-\mathrm{N}$ loss, flow-weighted mean concentration of $\mathrm{NO}_{3}^{-}-\mathrm{N}$ in the tile water was 


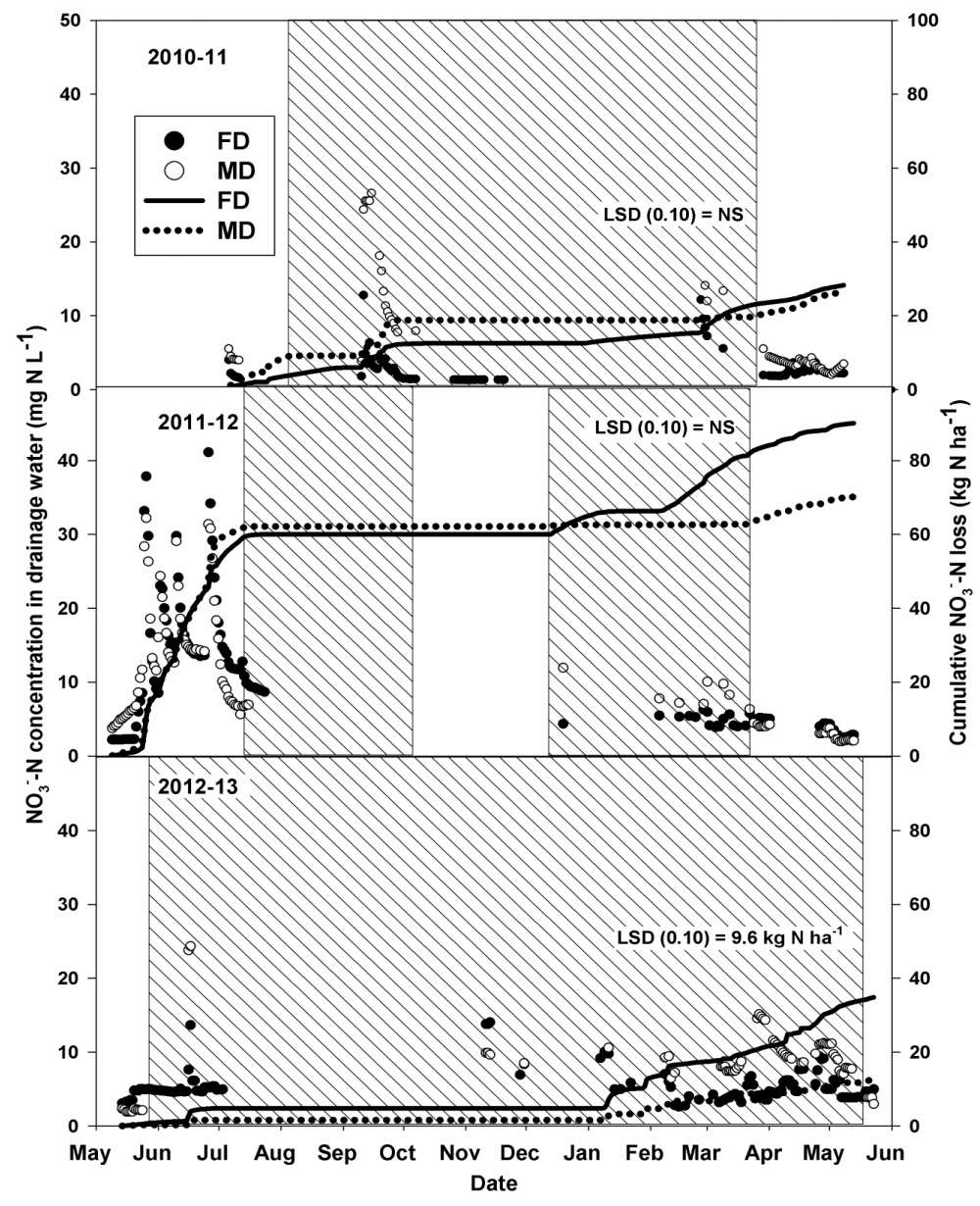

Figure 3. Daily concentration of $\mathrm{NO}_{3}^{-}-\mathrm{N}$ in tile drainage water (circles) and cumulative $\mathrm{NO}_{3}^{-}-\mathrm{N}$ loss (lines) by tile drainage treatment $(\mathrm{FD}=$ free drainage system and $\mathrm{MD}$ = managed drainage system) and years. The start of each study year corresponds to the spring $\mathrm{N}$ application. Shaded areas represent the period of time that MD treatments were in managed drainage mode. NS = not significant.

significantly $(\mathrm{P} \leq 0.05)$ affected by drainage systems during the MD period and the entire study year (Table 4). Over the FD period, flow-weighted mean concentration of $\mathrm{NO}_{3}^{-}-\mathrm{N}$ in the tile drainage water was similar between MD $\left(6.1 \mathrm{mg} \cdot \mathrm{N} \cdot \mathrm{L}^{-1}\right)$ compared to $\mathrm{FD}\left(5.9 \mathrm{mg} \cdot \mathrm{N} \cdot \mathrm{L}^{-1}\right)$. Over the MD period, flow-weighted mean concentration of $\mathrm{NO}_{3}^{-}-\mathrm{N}$ in the tile drainage water was $125 \%$ greater with $\mathrm{MD}\left(10.6 \mathrm{mg} \cdot \mathrm{N} \cdot \mathrm{L}^{-1}\right)$ compared to FD (4.7 $\left.\mathrm{mg} \cdot \mathrm{N} \cdot \mathrm{L}^{-1}\right)$. Increased flow-weighted mean concentration of $\mathrm{NO}_{3}^{-}-\mathrm{N}$ in the tile water with MD during the MD period as compared to the FD period was likely due to reduced tile flow, which has been reported between growing seasons with FD [13].

Average flow-weighted concentrations of $\mathrm{NO}_{3}^{-}-\mathrm{N}$ over a study year were greater with $\mathrm{MD}\left(8.1 \mathrm{mg} \cdot \mathrm{N} \cdot \mathrm{L}^{-1}\right)$ compared to FD $\left(5.8 \mathrm{mg} \cdot \mathrm{L} \cdot \mathrm{ha}^{-1}\right)$. Previous tile drainage research in corn production on upland soils have reported annual flow-weighted mean concentration of $\mathrm{NO}_{3}{ }^{-} \mathrm{N}$ in tile water in the range of 6 to $43 \mathrm{mg} \cdot \mathrm{N} \cdot \mathrm{L}^{-1}$ [10]-[13]. Annual flow-weighted mean concentration of $\mathrm{NO}_{3}^{-}-\mathrm{N}$ was below what was commonly reported in upland soils in corn production, as well as below the $10 \mathrm{mg} \cdot \mathrm{N} \cdot \mathrm{L}^{-1}$ required for drinking water standards [7]. This indicates that subsurface tile draining silty clay river bottom soils may not pose a health concern.

\section{Conclusion}

Similar to previous research on continuous corn in upland soils, cumulative $\mathrm{NO}_{3}^{-}-\mathrm{N}$ loss through tile drainage 
water with FD ranged from 28.3 to $90.1 \mathrm{~kg} \cdot \mathrm{N} \cdot \mathrm{ha}^{-1}$. High $\mathrm{NO}_{3}^{-}-\mathrm{N}$ loss in the tile drainage water in one of the study years was likely due to carry-over $\mathrm{N}$ from the previous season in combination with high tile flow due to wet conditions, as well as a presumably high water table due to the low landscape position that contributed to the tile water flow. Managed drainage was effective in reducing $\mathrm{NO}_{3}^{-}-\mathrm{N}$ though the tile drainage water (29\%) compared to FD over the three-year study. A reduction in $\mathrm{NO}_{3}^{-}-\mathrm{N}$ loss with MD compared to FD was primarily due to reduced tile flow over the non-cropping period. However, reduced tile flow with MD in combination with dry growing season conditions likely limited environmental $\mathrm{N}$ loss and corn $\mathrm{N}$ uptake during non-flow periods did result in slightly higher $\mathrm{NO}_{3}^{-}-\mathrm{N}$ concentration in the tile drainage water with $\mathrm{MD}$ compared to FD. However, flow-weighted mean concentration of $\mathrm{NO}_{3}^{-}-\mathrm{N}$ was rarely higher than the $10 \mathrm{mg} \cdot \mathrm{N} \cdot \mathrm{L}^{-1}$ drinking water standard. Therefore, tile draining river bottom soils for improved continuous corn production may not be a major health risk.

\section{Acknowledgements}

The authors thank the Missouri Fertilizer and Ag lime distributors for their financial support of this study. We would also like to thank Chris Dudenhoeffer, Clint Meinhardt, John Shetley, and Brandon Hebbert, for helping with the collection of water samples, as well as Ashley Hall for her contributions to the laboratory work required for this study.

\section{References}

[1] Watson, F.C. (1979) Soil survey for Knox, Monroe, and Shelby Counties, Missouri. United States Department of Agriculture, Soil Conservation Service, U.S. Gov’t Printing Off., 8-20.

[2] University of Missouri Extension (2009) Farm Land Values for Missouri Counties. University of Missouri. http://extension.missouri.edu/p/g403

[3] United States Environmental Protection Agency (1992) The National Water Quality Inventory. The 1992 Report to Congress. USEPA, Washington DC.

[4] Fausey, N.R., Brown, L.C., Belcher, H.W. and Kanwar, R.S. (1995) Drainage and Water Quality in Great Lakes and Cornbelt States. J. Irrig. Drain Eng., 121, 283-288. http://dx.doi.org/10.1061/(ASCE)0733-9437(1995)121:4(283)

[5] Gilliam, J.W., Baker, J.L. and Reddy, K.R. (1999) Water Quality Effects of Drainage in Humid Regions. In Skaggs, R.W. and Van Schilfgaarde, J., Eds., Agricultural Drainage. Agron. Monogr. 38. ASA, CSSA, and SSSA, Wisconsin, 801-830.

[6] Burkart, M.R. and James, D.E. (1999) Agricultural-Nitrogen Contributions to Hypoxia in the Gulf of Mexico. Journal of Environmental Quality, 28, 850-859. http://dx.doi.org/10.2134/jeq1999.00472425002800030016x

[7] United States Environmental Protection Agency (2009) National Primary Drinking Water Regulations. USEPA. http://water.epa.gov/drink/contaminants/upload/mcl-2.pdf

[8] Sims, J.T., Simard, R.R. and Joern, B.C. (1998) Phosphorus Loss in Agricultural Drainage: Historical Perspective and Current Research. Journal of Environmental Quality, 27, 277-293. http://dx.doi.org/10.2134/jeq1998.00472425002700020006x

[9] Adviento-Borbe, M.A., Kaye, J.P., Bruns, M.A., McDaniel, M.D., McCoy, M. and Harkcom S. (2010) Soil Greenhouse Gas and Ammonia Emissions in Long-Term Maize-Based Cropping Systems. Soil Science Society of America Journal, 74, 1623-1634. http://dx.doi.org/10.2136/sssaj2009.0446

[10] Gast, R.G., Nelson, W.W. and Randall, G.W. (1978) Nitrate Accumulation in Soils and Loss in Tile Drainage Following Nitrogen Applications to Continuous Corn. Journal of Environmental Quality, 7, 258-261. http://dx.doi.org/10.2134/jeq1978.00472425000700020021x

[11] Baker, J.L. and Johnson, H.P. (1981) Nitrate-Nitrogen in Tile Drainage as Affected by Fertilization. Journal of Environmental Quality, 10, 519-522. http://dx.doi.org/10.2134/jeq1981.00472425001000040020x

[12] Randall, G.W. and Vetsch, J.A. (2005) Nitrate Losses in Subsurface Drainage from a Corn-Soybean Rotation as Affected by Fall and Spring Application of Nitrogen and Nitrapyrin. Journal of Environmental Quality, 34, 590-597. http://dx.doi.org/10.2134/jeq2005.0590

[13] Drury, C.F., McKenney, D.J., Findlay, W.I. and Gaynor, J.D. (1993) Influence of Tillage and Nitrate Loss in Surface Runoff and Tile Drainage. Soil Science Society of America Journal, 57, 797-802.

[14] Drury, C.F., Tan, C.S., Rynolds, W.D., Welacky, T.W., Oloya, T.O. and Gaynor, J.D. (2009) Managing Tile Drainage, Subirrigation, and Nitrogen Fertilization to Enhance Crop Yields and Reduce Nitrate Loss. Journal of Environmental Quality, 38, 1193-1204. http://dx.doi.org/10.2134/jeq2008.0036 
[15] Evans, R.O., Skaggs, R.W. and Gilliam, J.W. (1995) Controlled Versus Conventional Drainage Effects on Water Quality. Journal of Irrigation and Drainage Engineering, 121, 271-276. http://dx.doi.org/10.1061/(ASCE)0733-9437(1995)121:4(271)

[16] Gilliam, J.W., Skaggs, R.W. and Weed, S.B. (1979) Drainage Control to Diminish Nitrate Loss from Agricultural Fields. Journal of Environmental Quality, 8, 137-142. http://dx.doi.org/10.2134/jeq1979.00472425000800010030x

[17] Evans, R.O., Skaggs, R.W. and Gilliam, J.W. (1990) Management Practice Effects on Water Quality. In: Harris, S.C., Ed., Proceedings of the 1990 National Conference, Irrigation and Drainage Division, ASCE, 182-191.

[18] Fogiel, A. and Belcher, H.W. (1991) Water Quality Impacts of Watertable Management Systems Annual Report. Dep. Agric. Eng., Michigan State University, Lansing.

[19] Fujinuma, R., Balster, N.J. and Norman, J.M. (2009) An Improved Model of Nitrogen Release for Surface-Applied Controlled-Release Fertilizer. Soil Science Society of America Journal, 73, 2043-2050. http://dx.doi.org/10.2136/sssaj2009.0085

[20] Nash, P.R., Nelson, K.A., Motavalli, P.P. and Meinhardt, C.G. (2012) Effects of Polymer-Coated Urea Application Ratios and Dates on Wheat and Subsequent Double-Crop Soybean. Agronomy Journal, 104, 1074-1084. http://dx.doi.org/10.2134/agronj2011.0235

[21] Nelson, K.A., Motavalli, P.P. and Dudenhoeffer, C.J. (2014) Cropping System Affects Polymer-Coated Urea Release and Corn Yield Response in Claypan Soils. Journal of Agronomy and Crop Science, 200, 54-65. http://dx.doi.org/10.1111/jac.12040

[22] Noellsch, A.J., Motavalli, P.P., Nelson, K.A. and Kitchen, N.R. (2009) Corn Response to Conventional and Slow-Release Nitrogen Fertilizers Across a Claypan Landscape. Agronomy Journal, 101, 607-614.

[23] Nelson, K.A. and Motavalli, P.P. (2013) Nitrogen Source, Drainage, and Irrigation Affects Corn Yield Response in a Claypan Soil. Applied Engineering in Agriculture, 29, 875-884. http://dx.doi.org/10.13031/aea.29.9809

[24] Nash, P.R. (2014) Utilization of Managed Subsurface Drainage Systems to Increase Corn and Forage Yields and Reduce Nitrogen Loss in Poorly-Drained, Upland and Bottomland Soils. Dissertation, University of Missouri, Columbia.

[25] Nathan, M., Stecker, J. and Sun, Y. (2006) Soil Testing in Missouri: A Guide for Conducting Soil Tests in Missouri. University of Missouri. http://soilplantlab.missouri.edu/soil/ec923.pdf

[26] Chun, J.A. and Cooke, R.A. (2008) Technical Note: Calibrating Agridrain Water Level Control Structures Using Generalized Weir and Orifice Equations. Applied Engineering in Agriculture, 24, 595-602. http://dx.doi.org/10.13031/2013.25274

[27] SAS Institute (2013) SAS 9.3. SAS Inst., Cary.

[28] Hernandez-Ramirez, G., Brouder, S.M., Ruark, M.D. and Turco, R.F. (2011) Nitrate, Phosphate, and Ammonium Loads at Subsurface Drains: Agroecosystems and Nitrogen Management. Journal of Environmental Quality, 40, 12291240. http://dx.doi.org/10.2134/jeq2010.0195

[29] Jaynes, D.B., Colvin, T.S., Karlen, D.L., Cambardella, C.A and Meek, D.W. (2001) Nitrate Loss in Subsurface Drainage as Affected by Nitrogen Fertilizer Rate. Journal of Environmental Quality, 30, 1305-1314.

[30] Qi, Z., Helmers, M.J., Christianson, R.D. and Pederson, C.H. (2011) Nitrate-Nitrogen Losses through Subsurface Drainage under Various Agricultural Land Covers. Journal of Environmental Quality, 40, 1578-1585. http://dx.doi.org/10.2134/jeq2011.0151 
Scientific Research Publishing (SCIRP) is one of the largest Open Access journal publishers. It is currently publishing more than 200 open access, online, peer-reviewed journals covering a wide range of academic disciplines. SCIRP serves the worldwide academic communities and contributes to the progress and application of science with its publication.

Other selected journals from SCIRP are listed as below. Submit your manuscript to us via either submit@scirp.org or Online Submission Portal.
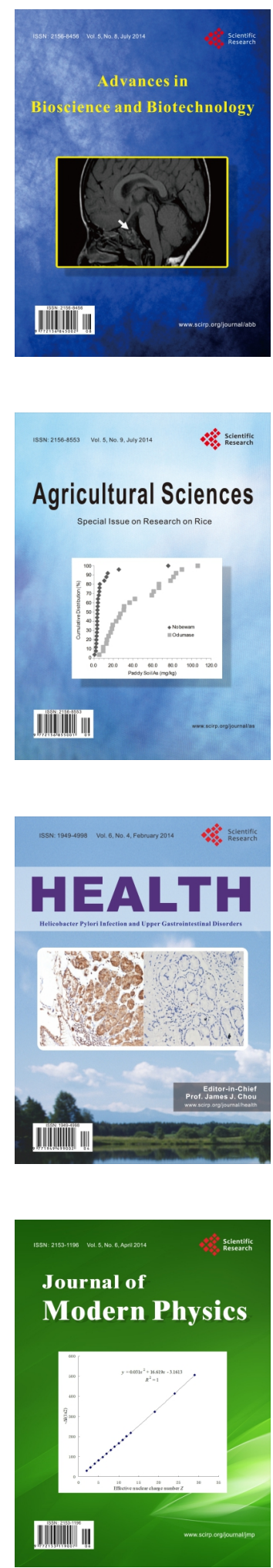
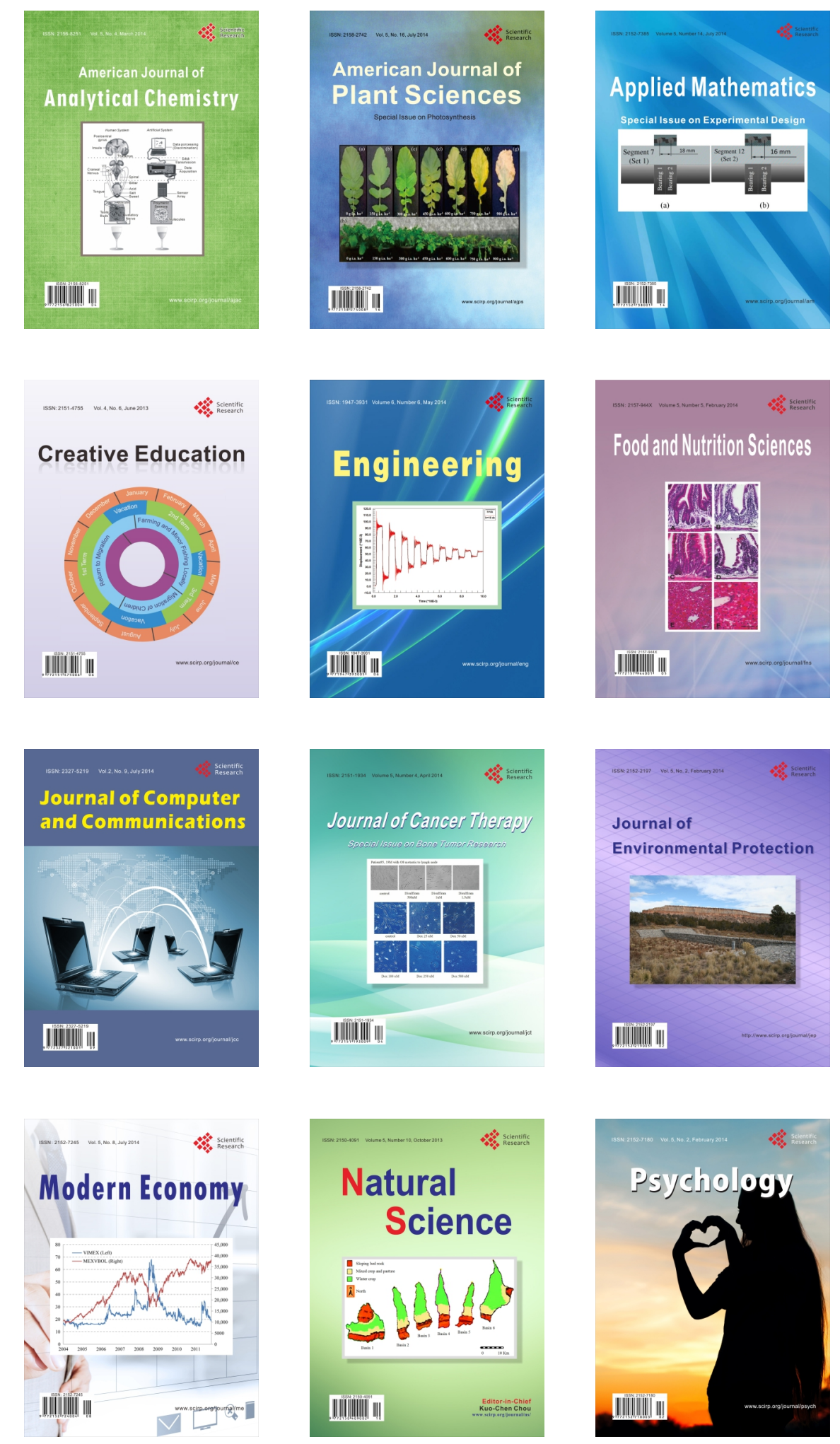